\title{
Applying the EU Solidarity ClaUse IN PRACTICE
}

\section{STOSOWANIE KLAUZULI SOLIDARNOŚCI UE W PRAKTYCE}

\begin{abstract}
The subject of the study is the solidarity clause introduced into the EU law system by the Treaty of Lisbon. Currently, it is in the article 222 the Treaty on the Functioning of the European Union. The aim of the study is to show its history, legal basis in the treaty regulations and in the secondary law and the way it operates. The work also shows the concerns and obstacles in its application. Particularly, the attention has been paid to its possible conflict with the concept of the sovereignty of the Member States. As a research hypothesis, the assumption has been made that the solidarity clause is a great opportunity for greater European integration by cooperating in the situations of threat to the security of the society in one of the Member States. As a final conclusion, it should be assumed that the solidarity clause is an important instrument of the Union's security policy. The method of dogmatic analysis of the law and the descriptive method were applied in the work.
\end{abstract}

\section{STRESZCZENIE}

Przedmiotem opracowania jest klauzula solidarności wprowadzona do systemu prawa unijnego traktatem lizbońskim. Obecnie znajduje się ona w art. 222 Traktatu o funkcjonowaniu Unii Europejskiej (TFUE). Celem opracowania jest ukazanie jej historii, podstaw prawnych w prawie traktatowym i wtórnym oraz sposobu jej funkcjonowania. W pracy zostały też ukazane obawy i przeszkody w jej stosowaniu. Szczególna uwaga została poświęcona jej ewentualnemu konfliktowi z koncepcją 
suwerenności państw członkowskich. Jako hipotezę badawczą przyjęto założenie, że klauzula solidarności jest ogromną szansą na większą ingerencję europejską poprzez współdziałanie w sytuacjach zagrażających bezpieczeństwu społeczeństwa jednego z państw członkowskich. Należy przyjąć wniosek końcowy, iż klauzula solidarności jest ważnym instrumentem polityki bezpieczeństwa unijnego. W pracy została zastosowana metoda analizy dogmatycznej przepisów prawa oraz metoda opisowa.

KEYWORDS: crisis management, terrorist attacks, European law, clauses in the European law, integration of activities

SŁOWA KLUCzowe: zarzadzanie kryzysowe, zamachy terrorystyczne, prawo europejskie, klauzule w prawie europejskim, integracja działań

\section{WPROWADZENIE}

Klauzula solidarności, zapisana w art. 222 na mocy traktatu lizbońskiego z dnia 13 grudnia 2007 r., została dodana do Traktatu o Funkcjonowaniu Unii Europejskiej (dalej: TFUE) (Dz.Urz. UE 2007 C nr 306, poz. 1). Jej celem jest udzielanie pomocy państwom członkowskim Unii w przypadku, gdy stanie się ono celem ataku terrorystycznego, ofiarą klęski żywiołowej czy katastrofy spowodowanej przez człowieka oraz zapobieganie takim zdarzeniom. W celu realizacji tych działań organy unijne zostały uprawnione do uruchomienia odpowiednich instrumentów, w tym wojskowych, w celu oddalenia zagrożenia.

Głównym celem klauzuli solidarności jest umożliwienie podejmowania wspólnych działań na rzecz zwiększenia bezpieczeństwa cywilnego. Odrębną kwestią jest realizacja tej klauzuli w praktyce. Stąd w pracy zostanie przedstawiona nie tylko idea klauzuli solidarności, ale również ocena jej efektywności. Należy bowiem wskazać na funkcjonujące w mediach i polityce niektórych państw członkowskich negatywne oceny dotyczące stosowania solidarity clause (Mydral, Rhinard, 2010). Wielu polityków europejskich jednak wyraźnie wskazuje na niezwykle pozytywną jej rolę w podejmowaniu działań na rzecz organizacji cywilnej ochrony mieszkańców państw członkowskich.

Sama klauzula była przedmiotem dość licznych opracowań naukowych (Ondrza, Parkes, 2010, s. 1) i popularno-naukowych (Novak, Raffaelli, 2017). Znalazła odzwierciedlenie w wielu aktach normatywnych Unii Europejskiej [np. European Programme for Critical Infrastructure Protection z 12 grudnia 2006 r. - COM(2006) 786 finale, czy też pkt 19-23 Rezolucji Parlamentu Eu- 
ropejskiego z dnia 22 listopada 2012 r. w sprawie klauzul wzajemnej obrony i solidarności UE: wymiaru politycznego i operacyjnego (2012/2223 (INI)) (2015/C 419/21)]. Nowością niniejszego opracowania jest przedstawienie uzgodnień dotyczących zastosowania przez Unię klauzuli solidarności na podstawie decyzji Rady z dnia 24 czerwca 2014 r. (2014/415/UE).

\section{DEKLARACJA SOLIDARNOŚCi Z 2004 R.}

Klauzula solidarności wprowadzona do europejskiego porządku prawnego traktatem lizbońskim w 2007 r. była poprzedzona licznymi aktami prawnymi międzynarodowymi i unijnymi, które wzywały państwa członkowskie do podejmowania solidarnych działań na rzecz zwalczania terroryzmu. Bezpośrednią przyczyną zwiększonej aktywizacji legislacyjnej w tym zakresie i oparciu wspólnych działań za solidaryzmie było wydarzenie z 11 września 2001 r., czyli zamachy terrorystyczne na Word Trade Center w Nowym Jorku. Wydarzenie to, niezwykle szokujące światową społeczność, pokazujące nowe sposoby zamachów terrorystycznych przeprowadzonych na wielką skalę, było uderzeniem w bezpieczeństwo cywilne czy wewnętrzne USA. Ale stanowiło początek analogicznego zagrożenia dla innych państw.

Stosownie do nowego zagrożenia terrorystycznego zostały podjęte działania przez Organizację Narodów Zjednoczonych. Przede wszystkim należy wskazać na rezolucję S/RES/1373 z 28 września 2001 r., na podstawie której państwa członkowskie ONZ zobowiązały się do przedsięwzięcia szeregu środków w zakresie przeciwdziałania aktom terrorystycznym. Postanowienia tej rezolucji są kontynuacją obowiązku współdziałania państw członkowskich przeciwko zagrożeniom dla bezpieczeństwa wewnętrznego, jaki został zapisany w art. 5 traktatu waszyngtońskiego z 4 kwietnia 1959 r. (Dz.U. z 2000 r. nr 87, poz. 970). W traktacie tym państwa członkowskie NATO, europejskie i amerykańskie, zobowiązały się do udzielania sobie nawzajem pomocy w razie napaści na jedno z nich. Zbrojna napaść na jedno z państw członkowskich NATO winna być traktowana jako napaść przeciwko nim wszystkim.

Dla UE duże znaczenie miała rezolucja Rady Bezpieczeństwa ONZ S/ RES/1267 (1999), która została wdrożona jako rozporządzenie Rady (WE) nr 881/2002 z 27 maja 2002 r. wprowadzające niektóre szczególne środki ograniczające skierowane przeciwko niektórym osobom i podmiotom 
związanym z Osamą bin Ladenem, siecią Al-Kaida i talibami [Dz.U. L 139 z 29 maja 2002 r., s. 9. Rozporządzenie zmienione rozporządzeniem (WE) nr 14/2007 (Dz.U. L 6 z 11 stycznia 2007 r., s. 6)]. Celem tego rozporządzenia było osłabienie podstaw gospodarczych organizacji terrorystycznych. Powodzenie przyjętych rozwiązań uzależniono jednak od współdziałania państw członkowskich, czyli od solidarności między nimi.

W dniu 25 marca 2004 r. podczas wiosennego szczytu Rady Europejskiej przyjęto Deklarację solidarności w zakresie zwalczania terroryzmu (Declaration on combating terrorism: extract concerning the establishment of the position of a Coordinator). Przyjęcie tej deklaracji było następstwem zamachów terrorystycznych, jakie miały miejsce 11 marca 2014 r. w Madrycie. Wyraźnie nawiązano do tych wydarzeń we wprowadzeniu do tego dokumentu. Deklaracja odnosi się do Europejskiej Strategii Bezpieczeństwa z 2003 r., w której terroryzm uznano za jedno z największych grożeń międzynarodowych (Górka-Winter, 2004, s. 1093).

W pkt 2 Deklaracji państwa członkowskie zostały wezwane do włączenia się w działania skierowane przeciwko terroryzmowi. Instrumentem bazowym do zwalczania terroryzmu miało być opracowanie długofalowej strategii zwalczania terroryzmu we wszelkich jego przejawach. W dokumencie tym zaznaczono, że celem klauzuli i działań z nią związanych jest zwiększenie bezpieczeństwa obywateli, a także rezydentów i osób podróżujących po krajach unijnych.

Przejawem klauzuli solidarności, według Deklaracji z 2004 r., winna być większa i bardziej efektywna współpraca pomiędzy organami wymiaru sprawiedliwości państw członkowskich. W załączniku I do Deklaracji określono siedem celów strategicznych, służących do wdrażania klauzuli solidarności, które można zgrupować w trzy obszary problemowe:

- ujednolicanie ustawodawstwa w zakresie europejskiego nakazu aresztowania, ustawodawstwa będącego podstawą do zwalczania terroryzmu, prania brudnych pieniędzy, identyfikacji sprawców przestępstw, wspierania działalności Europejskiej Jednostki Współpracy Sądowej (Eurojust);

- wzmocnienie i koordynacja działań operacyjnych, zwłaszcza tych, które są podejmowane przez policję i inne służby bezpieczeństwa. W tym zakresie konieczne jest wpieranie działań agencji europejskich, zwłasz- 
cza wspomnianej już agencji Eurojust, a także Europolu. Ta ostatnia agencja ma duże znaczenie dla koordynacji działań państw członkowskich z unijnymi strategiami w zwalczaniu terroryzmu;

- maksymalizacja efektywności systemów informacyjnych. Przywódcy państw członkowskich mieli na myśli usprawnienie funkcjonalności Systemu Informacyjnego Schengen (SIS).

Klauzula solidarności (spirit of the Solidarity Clause) została zapisana w art. I-43 ust. 1 projektu z 29 października 2004 r. Konstytucji dla Europy (ten traktat nie został ratyfikowany przez Francję i Holandię, w związku z czym nie wszedł w życie). Niezwykle jednak ważne jest to, że w projekcie tym klauzula solidarności została poszerzona o nowe działania wymagające odwołania się do zasady solidaryzmu, tj. o klęski żywiołowe oraz katastrofy sprowokowane przez człowieka.

Pierwotne znaczenie klauzuli solidarności zostało rozszerzone poprzez połączenie jej z założeniami przyjętymi przez program działań w dziedzinie ochrony ludności cywilnej. Na podstawie decyzji Rady z 23 października 2001 r. został ustanowiony wspólnotowy mechanizm ułatwiający wzmocnioną współpracę w działaniach interwencyjnych wspierających ochronę ludności cywilnej. Jednak klauzula solidarności nie zastępuje programu działań w dziedzinie ochrony ludności, a jest tylko jego uzupełnieniem. Program ten ma swoje instrumenty i odpowiednie organy odpowiedzialne za jego realizację.

Celem nowej instytucji było wzmocnienie współpracy między organami Unii a odpowiednimi organami państw członkowskich odpowiedzialnymi za cywilną ochronę ludności na wypadek wystąpienia poważnej sytuacji krytycznej lub jej bezpośredniej groźby, która może wymagać natychmiastowego działania. Mechanizm ten ma na celu zapewnienie lepszej ochrony ludzi, ich majątku, środowiska naturalnego i dziedzictwa kulturowego. Zagrożenia, którym ma zapobiegać, mogą być wynikiem katastrof naturalnych, technologicznych, radiologicznych lub pochodzić z samego środowiska (Barcik, 2007, s. 161).

W końcowym fragmencie europejskiej Deklaracji solidarności z 2004 r. postanowiono, że Unia Europejska zobowiązuje się do solidarnego działania nie tylko w przypadku wspomnianych zagrożeń, ale również w celu 
ochrony instytucji demokratycznego państwa i ludności cywilnej na wypadek poważnego ataku terrorystycznego.

Szczegółowe wytyczne co do stosowania klauzuli solidarności zostały określone w art. III-329 ust. 2 projektu Konstytucji dla Europy. Na podstawie tego przepisu, po wpłynięciu wniosku państwa członkowskiego o udzielnie pomocy, na wniosek Komisji i ministra spraw zagranicznych Unii, Rada miała przyjmować decyzję określającą warunki zastosowania klauzuli solidarności w konkretnym przypadku.

\section{ISTOTNE ZAŁOŻENIA KLAUZULI SOLIDARNOŚCI}

U podstaw treści klauzuli solidarności znajduje się koncepcja wspólnotowości, która połączona jest z kolei z ideą solidaryzmu społecznego. Współczesne społeczeństwo, także Unii Europejskiej, jest bardzo mocno zróżnicowane kulturowo i politycznie, co ma swoje korzenie m.in. w historii Europy i jej poszczególnych państw. Mimo różnorodności kulturowej, społecznej czy politycznej mieszkańców Unii więcej łączy, niż dzieli. Wspólnotowość w różnorodności rodzi odpowiedzialność jednych za drugich - solidarité (Ekengren, Matzén, 2006, s. 457 i n.).

Traktatem z Lizbony wprowadzona została możliwość podejmowania działań prewencyjnych, ale również obowiązek udzielenia pomocy wszystkim państwom członkowskim na wypadek zaistnienia klęski żywiołowej czy też ataku terrorystycznego. Przewidziana została zatem stała współpraca strukturalna, dzięki której ludność cywilna zyskała większą ochronę m.in. dzięki wzmocnieniu gotowości bojowej jednostek wojskowych. Dodatkowo zaś działania podejmowane na podstawie klauzuli solidarności mogą być realizowane na terenie pozawspólnotowym, jeśli ich oddziaływanie wpływałoby w jakikolwiek sposób na jedno z państw członkowskich. Konkretne działania muszą być akceptowane przez większość kwalifikowaną w Radzie.

Najistotniejsze jednak jest to, że jakiekolwiek z ww. zdarzeń rodzi obowiązek współdziałania państw i ich współpracy z organami unijnymi. Tego typu zdarzenie traktowane jest zaś tak, jakby bezpośrednio dotyczyło każdego z państw członkowskich. Na tym polega idea solidarności. Z klauzuli tej mogą korzystać wszystkie państwa członkowskie Unii na równych zasadach, niezależnie od wielkości i poziomu rozwoju ekonomicznego. 
Klauzula solidarności nie zastępuje działań państw członkowskich. Jest ona elementem polityki pomocniczości Unii Europejskiej. Powinna mieć zatem zastosowanie jedynie w sytuacjach wyjątkowych. Państwa muszą stosować i inwestować we własne zdolności w zakresie bezpieczeństwa i reagowania na klęski i katastrofy. To one same ponoszą odpowiedzialność za ochronę ludności i bezpieczeństwo na swoich terytoriach. Zaś na klauzulę solidarności można „powoływać się w sytuacjach, które przerastają możliwości reagowania danego państwa członkowskiego, bądź gdy wymagana jest reakcja wielosektorowa, angażująca liczne podmioty, jednak uważa [się], że gdy państwo członkowskie zdecyduje się powołać na tę klauzulę, pomoc ze strony innych nie powinna być przedmiotem debaty; podkreśla [się], że solidarność oznacza również zobowiązanie do inwestowania w adekwatne zdolności krajowe i europejskie" [pkt 21 i 22 sprawozdania z dnia 31 października 2012 r. w sprawie klauzul wzajemnej obrony i solidarności UE: wymiaru politycznego i operacyjnego (2012/2223 (INI)].

Wprowadzenie klauzuli solidarności należy spostrzegać nie tylko w perspektywie zacieśnienia współpracy między państwami członkowskimi w sytuacjach kryzysowych lub zagrożenia, ale również przez pryzmat ewentualnych konfliktów. Działania podejmowane na podstawie klauzuli mogą bowiem prowadzić - i w rzeczywistości prowadzą - do przynajmniej czasowego ograniczenia suwerenności państwa. Kwestia suwerenności państw członkowskich jest dość szeroko dyskutowana w literaturze, ale też staje się pożywką dla programów rożnych partii politycznych o podłożu narodowym.

W żadnym z traktatów, w tym również w Traktacie o Unii Europejskiej, nie ma przepisu, z którego wynikałoby, że przystąpienie do Unii powoduje ograniczenie suwerenności. Wskazuje się jednak na pewne czynniki, które mogą ograniczać suwerenność państw członkowskich, jak bezpośrednie obowiązywanie traktatów i rozporządzeń, implementacja dyrektyw, swoboda przemieszczania się osób przy jednoczesnej relatywizacji granic i inne. Słusznie jednak pisze Stanisław Konopacki, że we współczesnym świecie nie ma już możliwości stosowania kryteriów suwerenności, nawet tych, które obowiązywały jeszcze w I połowie XX w. Poszczególne państwa są związane traktatami, umowami gospodarczymi, militarnymi i politycznymi czy porozumieniami o współpracy, które co do zasady powodują ograniczenia 
suwerenności, o czym decydują zawsze władze polityczne poszczególnego kraju (Konopacki, 2008, s. 16). Unia nie ma określonego celu, którego desygnatem miałoby być ograniczenie suwerenności państw członkowskich i zstąpienie ich nowym państwem europejskim. Podejmowane zaś przez Radę Europejską decyzje są decyzjami suwerennych władz politycznych poszczególnych państw członkowskich.

Niewątpliwie klauzula solidarności w pewnym sensie może dokonywać czasowego ograniczenia suwerenności, jednak decyzja o ingerencji instrumentów unijnych czy też zastosowania środków przez inne państwa wspólnotowe może być podjęta tylko w przypadku zgody władzy politycznej danego państwa i współdziałania organów unijnych, o czym była mowa już wcześniej. Realizacja klauzuli ma na celu zapobieżenie lub też usunięcie negatywnych zdarzeń i ich skutków z terenu Unii.

W celu bliższego wyjaśnienia klauzuli solidarności można posłużyć się analogią do zasady o podwójnym skutku (art. 438 Kodeksu cywilnego), która stosowana jest w prawie cywilnym. Polega ona na tym, że w celu odwrócenia większego zła, zagrożenia, dokonuje się czasowego ograniczenia suwerenności konkretnego państwa. Suwerenność w tym przypadku, podobnie jak prawo własności, jest prawem elastycznym, może doznawać ograniczeń, ale po ustąpieniu zagrożenia powraca do swojej pełni. Wartość, jaką jest suwerenność państwa, nie może przeważać nad bezpieczeństwem obywateli w sytuacji zamachów terrorystycznych, katastrof naturalnych czy zdarzeń wywołanych działaniem człowieka.

Dodatkowym gwarantem zachowania suwerenności państw członkowskich jest zasada, że klauzula suwerenności może być uruchomiona jedynie na żądanie władz politycznych poszczególnego państwa członkowskiego. Nie jest zatem możliwe podjęcie działań przez ograny unijne lub też przez inne państwo członkowskie $\mathrm{z}$ własnej inicjatywy. Przeciwne zasady stosowano chociażby w dawnym Układzie Warszawskim, gdzie dla ratowania zdobyczy i idei socjalistycznych dopuszczano interwencję innych państw bez zgody władz politycznych państwa zainteresowanego, np. na Węgrzech w 1956 r. czy w Czechosłowacji w 1968 r.

Dzięki klauzuli solidarności Unia podejmuje próbę połączenia dotychczas oddzielnie prowadzonych działań w obszarze bezpieczeństwa militar- 
nego i obrony cywilnej. Koordynację działań podejmowanych na podstawie zasady klauzuli bezpieczeństwa zapewnia powołany do życia na podstawie pkt 14 Deklaracji z 2004 r. koordynator. Jego zadaniem jest koordynacja działań Rady dotyczących zwalczania terroryzmu, zaś obowiązkiem - składanie Radzie corocznie sprawozdania ze swojej działalności. Koordynator ponosi odpowiedzialność za swoje działania przed Komisją Europejską.

Postuluje się, aby Rada Europejska utworzyła wspólny system obronny przy pomocy europejskiej unii bezpieczeństwa na podstawie stałej współpracy strukturalnej oraz klauzuli zbiorowej obrony (art. 42 TUE). W tym celu proponuje się, aby w praktyce wykorzystać inne mające zastosowanie artykuły (art. 41 - fundusz początkowy, art. 44 powierzający misje w ramach Genezy Wspólnej Polityki Bezpieczeństwa i Obrony (WPBiO) grupie państw członkowskich oraz właśnie art. 222 TFUE, zawierający klauzulę solidarności (W kierunku europejskiej unii obronnej, 2015) (Martinelli, 2014, s. 432).

\section{DECYZJA 2014/415/UE RADY Z DNIA 24 CZERWCA 2014 R.}

Stosowanie wprowadzonej $\mathrm{z}$ dużym entuzjazmem $\mathrm{w}$ traktacie lizbońskim klauzuli solidarności (obecnie art. 222 TFUE) spotkało się z dość dużym oporem. Przyczyną tego był m.in. brak sysetmu wszczynania i wycofywania procedur umożliwiających stosowanie tej klauzuli w praktyce. Ponadto, nie do końca precyzyjne były podstawowe pojęcia związane z terminologią, przy pomocy której określano zdarzenia usprawiedliwiające zastosowanie klauzuli solidarności.

W art. 2 decyzji 2014/415/UE Rady określono zakres stosowania klauzuli. Zapisano, że może być ona stosowana na terytorium państw członkowskich, do których mają zastosowanie traktaty, w tym na obszarze lądowym, wód wewnętrznych, mórz terytorialnych i w przestrzeni powietrznej. Zdarzenia takie jak atak terrorystyczny, klęska żywiołowa czy katastrofy spowodowane przez człowieka, bez względu na to, czy powstały na, czy poza terytorium państw członkowskich, muszą wywierać wpływ na infrastrukturę krytyczną, np. na instalacje do wydobywania ropy naftowej i gazu ziemnego na obszarach morskich. Decyzja ta nie ma wpływu na kwestie obronne.

W art. 3 decyzji 2014/415/UE zdefiniowano podstawowe pojęcia. I tak, przez pojęcie „klęska żywiołowa lub katastrofa” rozumie się dowolną 
sytuację, która ma lub może mieć znaczący niekorzystny wpływ na ludzi, środowisko naturalne lub mienie, w tym na dziedzictwo kulturowe; przez pojęcie „atak terrorystyczny” rozumie się przestępstwo terrorystyczne zdefiniowane w decyzji ramowej Rady 2002/475/WSiSW [Decyzja ramowa Rady 2002/475/ WSiSW z dnia 13 czerwca 2002 r. w sprawie zwalczania terroryzmu (Dz.U. L 164 z 22 czerwca 2002 r., s. 2)]; przez pojęcie „sytuacja kryzysowa” rozumie się klęskę żywiołową, katastrofę lub atak terrorystyczny o tak daleko idących skutkach lub takim znaczeniu politycznym, że wymaga sprawnej koordynacji polityki i reakcji na szczeblu politycznym w Unii. Zdefiniowane zostało również pojęcie „reakcja”, które oznacza jakiekolwiek działanie podejmowane w przypadku klęski żywiołowej, katastrofy lub ataku terrorystycznego mające na celu zaradzenie ich bezpośrednim negatywnym skutkom.

$\mathrm{Z}$ punktu widzenia proceduralnego istotne znaczenie mają kolejne dwa artykuły decyzji 2014/415/UE, tj. art. 4 i 5. W art. 4 wprowadzono regułę, według której poszkodowane państwo członkowskie może powołać się na klauzulę solidarności dopiero po wyczerpaniu możliwości, jakie oferują istniejące środki i narzędzia na poziomie krajowym i unijnym. Konieczne jest też stwierdzenie, że dana sytuacja kryzysowa zdecydowanie przekroczyła dostępną dla tego państwa zdolność reagowania. Inicjatywa dotycząca zastosowania klauzuli należy do władz politycznych państwa członkowskiego. Wniosek ma być skierowany do prezydencji Rady oraz do przewodniczącego Komisji Europejskiej przez Emergency Response Coordination Center.

Powołanie się na klauzulę solidarności skutkuje tym, że Rada zobowiązana jest do zapewnienia politycznego i strategicznego kierownictwa i informuje wszystkie państwa członkowskie o powołaniu się na klauzulę solidarności. Uruchomiane są też wszystkie uzgodnienia podjęte w ramach Europejskiego Zarządzania Kryzysowego (Integrated Political Crisis Response) (Juchnicki, Nowakowski, Protasowicki, 2014). Przy tym określa się, jakie instrumenty, w tym wojskowe, mają zostać zastosowane w danej sytuacji kryzysowej. W działania mogą być włączone agencje europejskie, w zależności od potrzeb i rodzaju zagrożenia. Jednocześnie prowadzone są bieżące analizy przedstawiane w formie raportów. Spójność działań ma zapewnić prezydencja wspierana przez Sekretariat Generalny Rady, Komisję i Europejską Służbę Działań Zewnętrznych, a w przypadku ataku terrorystycznego również Koordynator UE 
ds. Zwalczania Terroryzmu. Po uruchomieniu klauzuli solidarności całodobowo i przez cały tydzień działa Centrum Koordynacji Reagowania Kryzysowego (Emergency Response Coordination Centre) (art. 5 Decyzji 2014/415/UE Rady).

Zasady wycofania się z klauzuli solidarności zostały określone w art. 7, zgodnie z którym wycofywanie przebiega zgodnie z procedurą określoną w art. 4 ust. 2, tj. władze polityczne danego państwa zwracają się z kolejnym wnioskiem do prezydencji i Komisji o zakończenie procedury stosowania klauzuli. Państwo członkowskie czyni tak wówczas, gdy uzna, że nie ma już potrzeby, by klauzula ta była aktywna.

Przykładem sytuacji zastosowania klauzuli solidarności mogą być pożary, jakie wybuchły latem 2007 r. w Grecji, głównie na Peloponezie. Były one skutkiem upałów i podpaleń. W wyniku szalejącego pożaru życie straciło ok. 63 osób, a destrukcji uległo 70 tys. ha lasów wraz z zabudowaniami. Akty podpaleń uznano za akty terrorystyczne (Grecja, 2007). Z wnioskiem do Komisji Europejskiej o podjęcie działań na podstawie art. 222 TFUE zwróciły się ówczesne greckie władze polityczne. W gaszeniu pożarów brało udział 20 państw członkowskich Unii.

Pod koniec pierwszej dekady obecnego wieku w Europie nasilił się ruch migracyjny. Napływająca fala uchodźców z Azji i Afryki zmusiła Komisję Europejską do podjęcia zdecydowanych kroków w celu zaradzania sytuacji. W 2015 r. podjęto decyzję o wprowadzeniu tymczasowej klauzuli solidarności dla krajów najbardziej dotkniętych skutkami fali uchodźców, tj. Włoch, Węgier i Grecji. Instrumentem będącym wyrazem solidarności ze strony państw członkowskich, a mającym rozwiązać problem uchodźczy (Sitek, 2016, s. 457-471), miała być relokacja 120 tys. uchodźców lub też wpłacenie do kasy unijnej 0,002\% PKB danego kraju. Środki te miały być przeznaczone na rozwiązanie problemu uchodźców (Komisja Europejska - komunikat prasowy).

Z kolei przykładem niezastosowania klauzuli solidarności były zamachy terrorystyczne, jakie miały miejsce we Francji, a konkretnie w Paryżu 13 listopada 2015 r. W związku z tymi dramatycznymi wydarzeniami minister obrony narodowej Francji Jean-Yves Le Drian wystąpił do Komisji Europejskiej o uruchomienie klauzuli pomocy i wsparcia, zapisanej w art. 42 ust. 7 TFUE, nie zaś klauzuli solidarności. „Zgodnie z tą klauzulą [pomocy i wsparcia] w razie napaści zbrojnej na terytorium jakiegokolwiek państwa 
członkowskiego pozostałe państwa członkowskie mają obowiązek udzielenia pomocy i wsparcia”. Był to pierwszy przypadek w historii UE powołania się przez kraj członkowski na tę klauzulę. Zgodę na jej zastosowanie wyrazili ministrowie obrony wszystkich 28 państw UE podczas spotkania, które odbyło się 17 listopada 2015 r. w Brukseli. Dokonano jednak kwalifikacji tych zdarzeń jako „zbrojna napaść, a nie „atak terrorystyczny”. W przypadku ataku terrorystycznego miałaby zastosowanie klauzula solidarności zawarta w art. 222 TFU, która również nakłada na państwa UE obowiązek pomocy zaatakowanemu krajowi, lecz jedynie w sprawach dotyczących polityki wewnętrznej i bezpieczeństwa narodowego (Gąsior, Majkowska, Potocka, 2015, s. 26).

\section{Podsumowanie}

Klauzula solidarności wprowadzona do systemu prawa unijnego w traktacie lizbońskim (obecnie art. 222 TFUE) jest ważnym instrumentem polityki bezpieczeństwa unijnego w obszarze bezpieczeństwa cywilnego w sytuacji zagrożenia zamachami terrorystycznymi skierowanymi przeciwko ludności cywilnej, katastrofami naturalnymi czy negatywnymi skutkami działań człowieka. Jej wprowadzenie było znaczącym wydarzeniem również dla ingerencji europejskiej. Zgodnie z przesłaniem ideologicznym tej klauzuli, zdarzenie powodujące zagrożenie dla ludności cywilnej w jednym z państw członkowskich powinno być traktowane jako zagrożenie terytorium każdego $\mathrm{z}$ tych państw.

Mimo to wielu polityków w państwach członkowskich zaczęło spostrzegać tę klauzulę jako zagrożenie dla suwerenności poszczególnych państw ze strony organów unijnych. Ten problem ma jednak marginalne znaczenie, bowiem współcześnie trudno jest uznać istnienie suwerenności państwa w duchu koncepcji z XIX czy z początku XX w. Każdy kraj musi współpracować $\mathrm{z}$ innymi i współpracuje na różnych płaszczyznach, dokonując samoograniczenia. W przypadku klauzuli solidarności trudno jest mówić o zagrożeniu dla suwerenności państw członkowskich, bowiem jej stosowanie zostało uzależnione od woli władz politycznych danego państwa.

Finalnie poważną przeszkodą w stosowaniu tej klauzuli okazał się brak odpowiednich procedur. Zostały one wprowadzone decyzją 2014/415/UE Rady. Należy uznać, że klauzula solidarności jest ważnym instrumentem obrony 
ludności cywilnej i jednocześnie instrumentem integracji europejskiej.

\section{Literatura}

Barcik, J. (2007). Wspólnotowy mechanizm ochrony ludności cywilnej, „Rocznik Bezpieczeństwa Międzynarodowego” Nr 2, s. 158-176. ISSN 1896-8848.

Ekengren, M., Matzén, N., Rhinard, M., Svantesson, M. (2006). Solidarity or sovereignty? EU cooperation in civil protection, „European Integration” $\mathrm{Nr} 28(5)$, s. $457-476$.

Gąsior, M., Majkowska, M., Potocka, M. (2015). Inne, „Przegląd Spraw Europejskich”, Warszawa: NBP, s. 25-27.

Górka-Winter, B. (2004). Plan Unii Europejskiej zwalczania terroryzmu, „Biuletyn”, Polski Instytut Spraw Międzynarodowych, Biuro Analiz, Nr 13(201), s. 1093-1095.

Juchnicki, M., Nowakowski, Z., Protasowicki I. (2014). System zarzadzania kryzysowego Unii Europejskiej. W: M. Ilnicki, Z. Nowakowski (red.). Wspótczesne wyzwania polityki bezpieczeństwa - wybrane zagadnienia, Warszawa: Towarzystwo Naukowe Powszechne. ISBN 9788361556213.

Konopacki, S. (2008). Problem suwerenności w Unii Europejskiej, „Studia Europejskie" Nr 3, Centrum Europejskie Uniwersytetu Warszawskiego, s. 9-22. ISSN 1428-149X.

Martinelli, F. (2014). Manuale di diritto dell'Unione Europea. Aspetti istituzionali e politiche dell'Unione, Napoli: Simone. ISBN 9788891414311.

Myrdal, S., Rhinard, M. (2010). The European Union's solidarity clause: Empty letter or effective tool, Stokholm: Swedish Institute of International Affairs. ISBN 9789171836649.

Sitek, M. (2016). Kryzys uchodźczy a kryzys instytucjonalny Unii Europejskiej, „Journal of Modern Science" 1/28, s. 457-471. ISSN 1734-2031.

von Ondarza, N., Parkes, R. (2010). The EU in the Face of Disaster: Implementing the Lisbon Treaty's Solidarity Clause. Stiftung Wissenschaft und Politik, s. 1-8. ISSN 1861-1761.

\section{Źródła internetowe}

Grecja: ogień szaleje w Arkadii, TVN24 z 28.08.2007, https://www.tvn24.pl/wiadomoscize-swiata,2/grecja-ogien-szaleje-w-arkadii,32494.html (dostęp: 11.11.2017).

Klauzula solidarności, Traktat o funkcjonowaniu Unii Europejskiej (TFUE) z 13 grudnia 2007 r. art. 222, http://eur-lex.europa.eu/summary/glossary/solidarity_ clause.html (dostęp: 11.11.2017). 
Komisja Europejska - Komunikat prasowy - Kryzys zwiazany z uchodźcami: zdecydowane działania Komisji Europejskiej Strasburg, 9 września 2015, http://europa.eu/ rapid/press-release_IP-15-5596_pl.htm (dostęp: 11.11.2017).

Novak, P. Raffaelli, R. (2017). Traktat z Lizbony, http://www.europarl.europa.eu/ atyourservice/pl/displayFtu.html?ftuId=FTU_1.1.5.html (dostęp: 9.11.2017).

W kierunku europejskiej unii obronnej (2015), http://www.eppgroup.eu/pl/ourpriority/W-kierunku-europejskiej-unii-obronnej (dostęp: 11.11.2017). 